\title{
Wheat phytotoxicity from arsenic and cadmium separately and together in solution culture and in a calcareous soil
}

\author{
Qing $\mathrm{Cao}^{\mathrm{a}}$, Qin-Hong $\mathrm{Hu}^{\mathrm{b}}$, Sardan Khan ${ }^{\mathrm{a}, \mathrm{c}}$, Zi-Jian Wang ${ }^{\mathrm{a}}$, \\ Ai-Jun Lin ${ }^{\mathrm{d}}$, Xin Du ${ }^{\text {a }}$, Yong-Guan Zhu ${ }^{\mathrm{a}, *}$ \\ ${ }^{a}$ Research Center for Eco-environmental Sciences, Chinese Academy of Sciences, Beijing 100085, PR China \\ ${ }^{\mathrm{b}}$ Lawrence Livermore National Laboratory, University of California, Livermore, CA 94550, USA \\ ${ }^{\mathrm{c}}$ Department of Environmental Sciences, University of Peshawar, 25120 Peshawar, Pakistan \\ ${ }^{\mathrm{d}}$ College of Chemical Engineering, Beijing University of Chemical Technology, Beijing 100029, PR China \\ Received 6 December 2006; received in revised form 18 February 2007; accepted 19 February 2007 \\ Available online 23 February 2007
}

\begin{abstract}
The toxicity of two toxic elements, arsenic (As) and cadmium (Cd) (individually or in combination) on root elongation of wheat seedlings (Triticum aestivum, L.) were investigated both in hydroponics and in soils freshly spiked with the toxic elements. Median effective concentration $\left(E_{50}\right)$ and non-observed effect concentration (NOEC) were used to investigate the toxic thresholds and potencies of the two elements. The $\mathrm{EC}_{50}$ for As was $0.97 \mu \mathrm{M}$ in hydroponics and $196 \mathrm{mg} \mathrm{kg}^{-1}$ in soil, and $4.32 \mu \mathrm{M}$ and $449 \mathrm{mg} \mathrm{kg}^{-1}$ for Cd, respectively. Toxic unit (TU) and additive index (AI) concepts were introduced to determine the combined outcomes, and different behaviors were obtained: synergism in solution culture $\left(\mathrm{EC}_{50 \mathrm{mix}}=0.36 \mathrm{TU}_{\text {mix }}\right.$ and $\left.\mathrm{AI}: 1.76\right)$ and antagonism in soil experiments $\left(\mathrm{EC}_{50 \mathrm{mix}}=1.49 \mathrm{TU}_{\text {mix }}\right.$ and $\mathrm{AI}$ : -0.33$)$. Furthermore, the data of soil bioavailable As and Cd cannot explain the discrepancy between the results derived from soil and hydroponics experiments.
\end{abstract}

(C) 2007 Elsevier B.V. All rights reserved.

Keywords: Arsenic; Cadmium; Phytotoxicity; Root elongation; Median effective concentration; Combined effect; Toxic unit; Additive index

\section{Introduction}

The adverse effects of toxic chemicals on soil fauna and microbes are of the major foci in soil ecotoxicological assessments. As for the effects to the flora, most tests or standard methodologies have been developed to primarily study the behavior of hydrophytes. Test on terrestrial plants has been recognized as an issue of high priority by many governmental agencies around the world $[1,2]$. The test methods related with phytotoxicity should be enhanced in assessing the impacts of chemicals on terrestrial ecosystem because vegetation is a functional component of terrestrial ecosystem, and crop also serve as an important pathway for human exposure to toxic elements [3].

Currently, some terrestrial plant tests were conducted $[1,2,4,5]$ to estimate the potential impacts of chemical on non-

\footnotetext{
* Corresponding author.

E-mail address: ygzhu@ rcees.ac.cn (Y.-G. Zhu).
}

target species, in order to investigate the effects of remediation [6] and to develop ecological soil screening levels [7]. There are several kinds of standardized plant toxicity tests, i.e. seed germination, root elongation, and early seedling growth tests. Photosynthesis inhibition test and enzyme content fluctuation are also frequently used as endpoints for phytotoxicity [8]. The present study selects wheat for testing as it is the main staple cereal in the world, especially in northern China. Furthermore, root elongation is selected as a quantitative test endpoint in this study as the root accumulate more toxicants, and is more sensitive, than shoot [2,9].

Current ecotoxicological assessments or criteria have generally been derived from data involving single toxicant, yet rarely is there only one contaminant present in field soils. Combined effects of chemicals should be taken into consideration in the development of ecotoxicologically relevant soil quality criterion. Arsenic and cadmium are two of the typical hazardous elements, and they are non-essential to plant [10,11]. Arsenic (As) was ranked as the No. 1 and cadmium $(\mathrm{Cd})$ as the No. 8 of hazardous substances which have significant potential threat 
to human health due to their known or suspected toxicity [12]. Phytotoxicity of single As or Cd was well documented [13,14], but little is known about their combined effects to plants when presented simultaneously in soil. A study performed by Sneller et al. to Silene Vulgaris in hydroponics shown the interaction of As and Cd is concentration- depended, and the element's uptake did not affected by another element [15]. While animal studies reported that As may exacerbate Cd toxicity to mice kidney [16].

The objective of this study is therefore to assess the plant toxic effects of As and Cd individually and in combination, and to determine the direction and extent of their interaction both in solution and in soil. To our knowledge, few studies have been published regarding the mixture toxicity of As and $\mathrm{Cd}$ to crop plants. Results from this study will help us realistically understand the phytotoxicity of soil As and Cd on plants.

\section{Materials and methods}

\subsection{Preparation of seedlings}

Seeds of wheat (Triticum aestivum, L., Zhongmai 9) were purchased from Chinese Academy of Agricultural Sciences, Beijing, China. Seeds were sterilized with $10 \%$ (w:w) hydrogen peroxides for $10 \mathrm{~min}$, followed by thorough washing with deionized water. The seeds were submerged in distilled water and cultured in a $37^{\circ} \mathrm{C}$ incubator for $24 \mathrm{~h}$. After the radicel appeared, seeds with uniform appearance were chosen for next procedure, i.e. germinated in moist perlite for hydroponics experiments, or embedded in test soil.

\subsection{Root elongation test in solution}

Six days after germination and initial growth period in perlite seedbed, the seedlings were gently removed from perlite and washed. After measuring the initial root length, groups of 10 seedlings were transferred to $500 \mathrm{ml}$ PVC pots $(7.5 \mathrm{~cm}$ in diameter and $15 \mathrm{~cm}$ in height), in which contained simple phosphate-free nutrient solution $\left(0.1 \mathrm{mM} \mathrm{MgSO}_{4}, 0.2 \mathrm{mM}\right.$ $\left.\mathrm{Ca}\left(\mathrm{NO}_{3}\right)_{2}, 0.2 \mathrm{mM} \mathrm{KNO}_{3}\right)$ and the target exposure concentration levels of toxicants [17]. All the hydroponics experiments were conducted with continuous aeration.

In the experiment with a single toxicant, concentrations of As $\left(\mathrm{Na}_{3} \mathrm{AsO}_{4} \cdot 12 \mathrm{H}_{2} \mathrm{O}\right.$, analytical reagent) or $\mathrm{Cd}\left(\mathrm{CdCl}_{2} \cdot 2.5 \mathrm{H}_{2} \mathrm{O}\right.$, analytical reagent) were targeted at the following levels: $0,0.01$, $0.03,0.1,0.33,1.00,3.33,10,33.3,100 \mu \mathrm{M}$. In the mixedtoxicant experiment, the treatments were set up according to the single toxicant data [18] and equitoxic mixture with a range of six concentrations $\left(0,0.4,0.8,1.2,1.6,2 \sum \mathrm{TU}\right)$. The equitoxic mixture approach is more reasonable than equi-concentration mixture one because it is supposed that $0.5 n \times \mathrm{EC}_{50}$ As and $0.5 n \times \mathrm{EC}_{50} \mathrm{Cd}$ had same toxicity and their mutual toxicity should be $1 n \times \mathrm{TU}_{\text {mix }}$. Three replicates were used for each concentration. The exposure time for all experiments was 6 days, and the culture solution was changed every 3 days to maintain the target concentration.
Table 1

Some physicochemical properties of the soil used in the experiment

\begin{tabular}{lllc}
\hline Parameters & Value & Parameters & Value \\
\hline pH $\left(\mathrm{H}_{2} \mathrm{O}, 1: 2.5\right.$ soil/water ratio) & 8.05 & Total As $\left(\mathrm{mg} \mathrm{kg}^{-1}\right)$ & 12.2 \\
$\mathrm{CEC}(\mathrm{cmol} / \mathrm{kg})$ & 17.0 & Total Cd $\left(\mathrm{mg} \mathrm{kg}^{-1}\right.$ & 0.04 \\
Organic matter $(\mathrm{g} / \mathrm{kg})$ & 20.4 & Total Cu $\left(\mathrm{mg} \mathrm{kg}^{-1}\right)$ & 31.7 \\
Sand (\%) & 45.99 & Total Zn $\left(\mathrm{mg} \mathrm{kg}^{-1}\right)$ & 61.2 \\
Silt $(\%)$ & 47.75 & Total Cr $\left(\mathrm{mg} \mathrm{kg}^{-1}\right)$ & 60.3 \\
Clay (\%) & 6.26 & Total Pb $\left(\mathrm{mg} \mathrm{kg}^{-1}\right.$ & 22.6 \\
Soil texture & Silt loam & Total Mn $\left(\mathrm{mg} \mathrm{kg}^{-1}\right)$ & 559 \\
Total P $\left(\mathrm{mg} \mathrm{kg}^{-1}\right)$ & 887 & Total Ni $\left(\mathrm{mg} \mathrm{kg}^{-1}\right)$ & 296 \\
\hline
\end{tabular}

\subsection{Root elongation test in spiked soil}

A sample of non-contaminated soil was collected from the suburb of Beijing $\left(\mathrm{N} 39^{\circ} 52.15^{\prime}, \mathrm{E} 116^{\circ} 37.39^{\prime}\right)$, air dried and sieved through $2 \mathrm{~mm}$ griddle. The basic physical and chemical properties of the soil were measured and listed in Table 1. Determination of Soil $\mathrm{pH}$ was conducted with the soil:water ratio of 1:2.5 [19]. Organic matter was measured with hot $\mathrm{K}_{2} \mathrm{Cr}_{2} \mathrm{O}_{4}$ oxidization and $\mathrm{FeSO}_{4}$ titration, and cation exchange capacity (CEC) by the $\mathrm{NH}_{4} \mathrm{OAC}$ methods [20]. Soil texture was classified according to the contents of clay, silt and sand, which were determined by laser diffraction system (Malvern Master Sizer 2000, Malvern Co., England) after the soil particles diffused in $0.5 \mathrm{M} \mathrm{NaPO}_{3}$ solution. Total contents of soil elements were determined by ICP-AES (Optima 2000 DV, Perkin-Elmer Co. USA) after the digestion with aqua regia [21].

$\mathrm{As}(\mathrm{V})$ and/or Cd solution was spiked to soil to make certain contamination levels in the soil. The spiked soil was then air dried, passed a $2 \mathrm{~mm}$ sieve again and aged for at least 1 week before root elongation test. A mass of $300 \mathrm{~g}$ soil was transferred to a plastic cup; ten germinated wheat seeds were then embedded just beneath the surface and checked daily to keep the moisture at $20 \%(\mathrm{v} / \mathrm{w})$. After the seeds grew for 3 days, the seedlings were collected and the main root lengths measured. The arsenate concentrations in eleven soil-arsenate treatments were 0 , $2.5,5,10,20,40,60,90,135,200,300 \mathrm{mg} \mathrm{kg}^{-1}$, while the fourteen cadmium treatments are $0,2.5,5,10,20,40,60,90,135$, $200,300,450,675,1000 \mathrm{mg} \mathrm{kg}^{-1}$. The combined test had nine concentrations $\left(0,0.1,0.2,0.4,0.8,1.2,1.6,2,3.2 \sum \mathrm{TU}\right)$; three replicates were used for each concentration.

\subsection{Growth conditions}

The experiments were carried out in a growth chamber set with a 14-h light/10-h dark photoperiod (260$350 \mu \mathrm{mol} \mathrm{m}{ }^{-2} \mathrm{~s}^{-1}$ ), a day/night temperature of $25 / 20^{\circ} \mathrm{C}$ and a relative humidity of $70 \%$

\subsection{Statistical analysis}

NOEC was determined by Dunnett program, Version 1.5 (USEPA). If a significant $F$ value of $P<0.05$ was obtained, a Dunnett's multiple comparison versus the control group analysis was conducted [22]. EC 50 calculation was performed by the regression method using SigmaPlot 9.0 (SPSS Inc., Chicago, 
IL). Logistic formula (Eq. (1)) of 3 parameters as following was chosen for its good fitness [23]. Parameter $y$ is the wheat root length, $x$ the concentration, $a$ the expected root length of wheat when $x=0, x_{0}$ the median effective concentration $\left(\mathrm{EC}_{50}\right)$ and $b$ is the slope parameter.

$y=\frac{a}{1+\left(x / x_{0}\right)^{b}}$

\subsection{Principles for preparing mixture and determining combined effects}

The concept of toxic unit was proposed by Sprague and Ramsay [24] to express the effect concentration of a chemical, and later proved useful in mixture toxicity studies. Toxic unit is nondimension value calculated by the ratio of concentration and $\mathrm{EC}_{50}$. One toxic unit means the toxic concentration is nearly $\mathrm{EC}_{50}$. According to the toxic data of single As and Cd, the mixedtoxicant experiments were prepared as Eqs. (2) and (3) and with equitoxic ratio hypothesis $[18,25]$. The combined effect of mixture $\left(\mathrm{EC}_{50 \mathrm{mix}}\right)$ was calculated by regression, and expressed with $\mathrm{TU}_{\text {mix }}$, then compared with expected effects from concentration additive $\left(1 \mathrm{TU}_{\text {mix }}\right)[26,27]$. If the $\mathrm{EC}_{50 \text { mix }}$ would not significantly differs from $1 \mathrm{TU}_{\mathrm{mix}}$, the effect of two toxicants is concentration additive. If the $\mathrm{EC}_{50 \mathrm{mix}}$ would be significantly lower (or higher) than $1 \mathrm{TU}_{\text {mix }}$, then less (or higher) than concentration additive mode is derived about the toxicants interaction.

$\mathrm{TU}=\frac{\text { Conc. }}{\mathrm{EC}_{50}} \quad$ (for single toxicant)

$\mathrm{TU}_{\text {mix }}=\sum \mathrm{TU}=\mathrm{TU}_{\mathrm{As}}+\mathrm{TU}_{\mathrm{Cd}}$

Marking and Dawson [28] proposed an original method of additive index (AI), which can quantitatively describes additive toxicity of chemicals. Sum of the toxicity $(S)$ of chemical A and $\mathrm{B}$ was determined by Eq. (4), $i$ and $m$ are the $\mathrm{EC}_{50}$ of the individual and the mixture. By transforming to additive index (Eq. (5)), it is easy to judge whether the combined effect is less than or greater than additive just by recognizing the value of AI is negative or positive.

$S=\frac{A_{m}}{A_{i}}+\frac{B_{m}}{B_{i}}$

$\mathrm{AI}=\frac{1}{S}-1 \quad(S \leq 1)$ or $\mathrm{AI}=S(-1)+1 \quad(S \geq 1)$

\section{Results and discussion}

\subsection{Single toxicity in solution culture}

Concentration-effect curves (Figs. 1 and 2) were plotted from the data of single toxicant exposures. From the figures, it can be seen that As and Cd had different curve shapes, the values of the slope parameter $b$ were 2.73 for As and 0.97 for $\mathrm{Cd}$. The two toxicants had the similar toxic threshold of $0.33 \mu \mathrm{M}$, but the concentrations with an inhibition rate larger than $>95 \%$ were 3.3 and $100 \mu \mathrm{M}$ for $\mathrm{As}$ and $\mathrm{Cd}$, respectively, which has a 30-

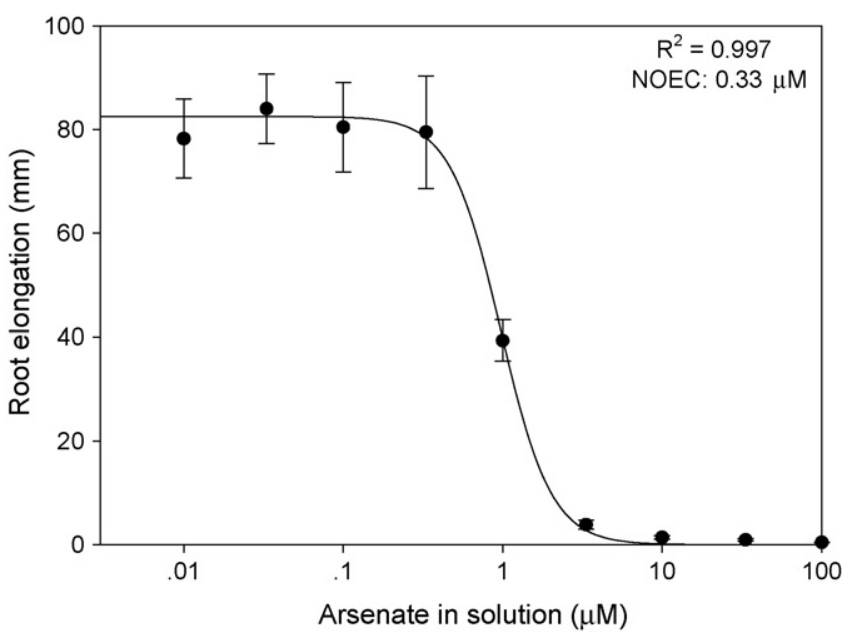

Fig. 1. Observed responses and fitted curve of wheat root to arsenate in solution. NOEC was assessed using Dunnett's procedure (at a 5\% significance level) on the data. Error bar stands for standard error.

fold difference. The $\mathrm{EC}_{50}$ values were 0.97 and $4.32 \mu \mathrm{M}$ for $\mathrm{As}$ and $\mathrm{Cd}$, respectively.

Data on arsenate toxicity from our solution culture experiment are much higher than the results of Liu et al. [29], who exposed six varieties of wheat to arsenate in solution for 2 days and the median effective concentrations of the root length were about $4-16 \mathrm{mg} / \mathrm{L}$. Similarly, a reported $\mathrm{Cd} \mathrm{EC}_{50}$ for wheat elongation was $66 \mathrm{mg} / \mathrm{L}$ [30], which greatly differs from our solution results. These differences indicate that the early-stage test with simple solution, an approach used in this study, seems to be a more sensitive method to identify toxic substances.

\subsection{Combined toxicity in solution culture}

In the experiment with mixed toxicants, a set of increasing equitoxic concentrations of toxicants was arranged based on the single exposure data. The solutions with $0.4,0.8,1.2,1.6$, $2 \mathrm{TU}_{\text {mix }}$ were composed according to Table 2 . Using $\mathrm{TU}_{\text {mix }}$ as

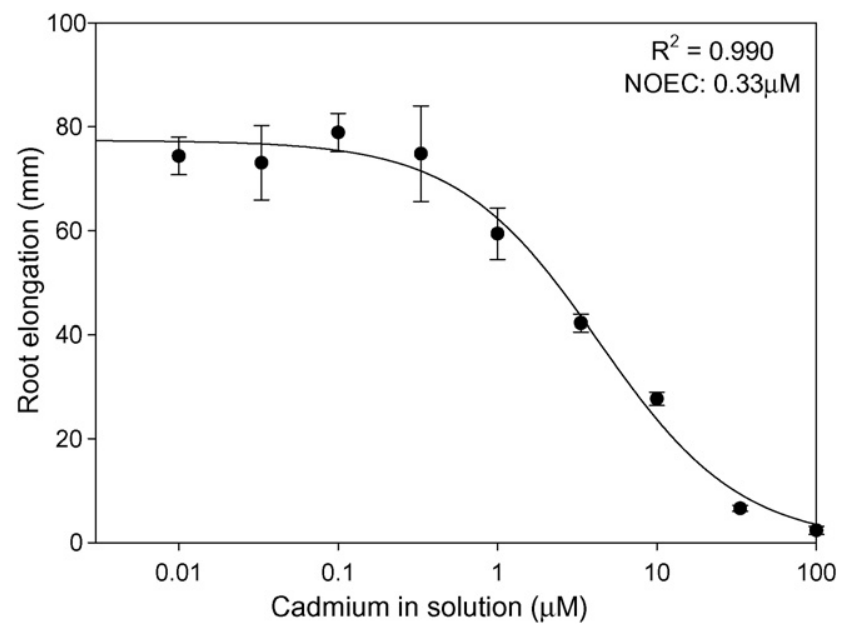

Fig. 2. Observed responses and fitted curve of wheat root to cadmium in solution. NOEC was assessed using Dunnett's procedure (at a 5\% significance level) on the data. Error bar stands for standard error. 
Table 2

Composition of combined test in solution experiment

\begin{tabular}{ll}
\hline Treatment $\left(\mathrm{TU}_{\text {mix }}\right)$ & $\begin{array}{l}\text { As conc. }(\mu \mathrm{M})\left(\mathrm{TU}_{\mathrm{As}}\right)+\mathrm{Cd} \text { conc. } \\
(\mu \mathrm{M})\left(\mathrm{TU}_{\mathrm{Cd}}\right)\end{array}$ \\
\hline $1(0)$ & $0(0)+0(0)$ \\
$2(0.4)$ & $0.19(0.2)+0.86(0.2)$ \\
$3(0.8)$ & $0.39(0.4)+1.73(0.4)$ \\
$4(1.2)$ & $0.58(0.6)+2.58(0.6)$ \\
$5(1.6)$ & $0.78(0.8)+3.46(0.8)$ \\
$6(2)$ & $0.97(1)+4.32(1)$
\end{tabular}

the horizontal axis, instead of the real concentration, the combined effect curve (Fig. 3) produced a regression result of $\mathrm{EC}_{50}$ at $0.36 \mathrm{TU}_{\text {mix }}$. This means that solution containing $0.17 \mu \mathrm{M}$ As $\left(0.18 \mathrm{TU}_{\mathrm{As}}\right)$ plus $0.78 \mu \mathrm{M} \mathrm{Cd}\left(0.18 \mathrm{TU}_{\mathrm{Cd}}\right)$ could inhibits $50 \%$ root elongation. The value of AI was 1.76 (ranging from 1.17 to 2.55). It is obvious that mixture exposure of arsenate and cadmium in solution has a significant great than additive toxicity to wheat root.

\subsection{Single toxicity in soil}

Figs. 4 and 5 showed the concentration-effect curves of wheat in the soils spiked with As or Cd. The curve shape for As was steeper than $\mathrm{Cd}$ ( $b$ value of 3.32 for As and 0.91 for $\mathrm{Cd}$ ). Soil As had a toxic threshold of $40 \mathrm{mg} \mathrm{kg}^{-1}$ with a higher than $80 \%$ root inhibition rate at $300 \mathrm{mg} \mathrm{kg}^{-1}$; while the threshold for soil Cd was found to be $20 \mathrm{mg} \mathrm{kg}^{-1}$, but even at the largest concentration of $1000 \mathrm{mg} \mathrm{kg}^{-1}$ only $67 \%$ inhibition rate for root elongation was observed. The soil $\mathrm{EC}_{50}$ was $196 \mathrm{mg} \mathrm{kg}^{-1}$ for $\mathrm{As}(\mathrm{V})$ and $449 \mathrm{mg} \mathrm{kg}^{-1}$ for $\mathrm{Cd}$. In other words, $\mathrm{As}(\mathrm{V})$ toxicity is about 2.3 times of that for $\mathrm{Cd}$ in the tested soil.

Toxicity data of soil As are in line with several other studies. Song et al. [31] performed 4-days' barley root growth tests with 16 European soils, and the $\mathrm{EC}_{50}$ values for freshly spiked arsenate varied from 26.6 to $458.2 \mathrm{mg} \mathrm{kg}^{-1}$. The $\mathrm{EC}_{50}$ value of soil Cd obtained in this study $\left(449 \mathrm{mg} \mathrm{kg}^{-1}\right)$ is larger than a similar test $\left(98 \mathrm{mg} \mathrm{kg}^{-1}\right)$ by An [9], who used the

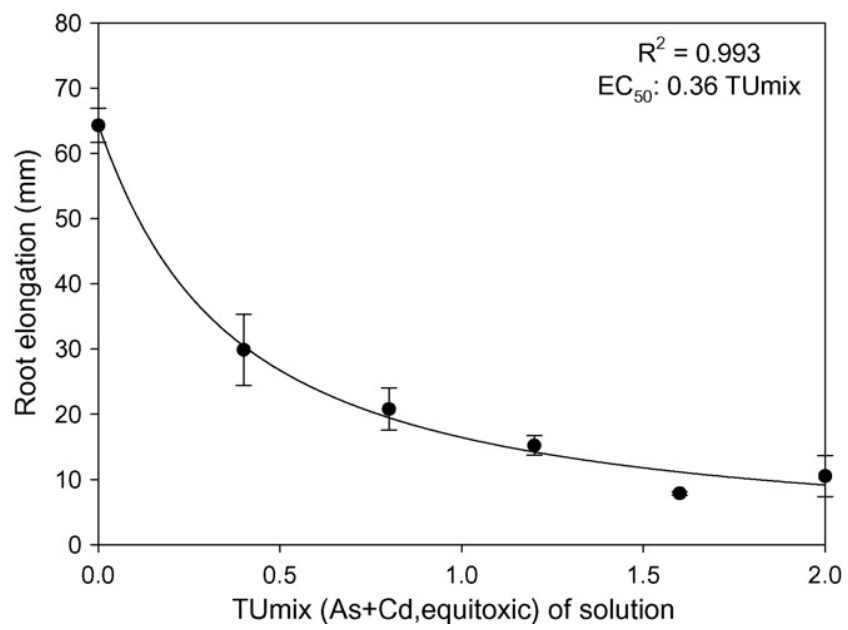

Fig. 3. Responses and fitted curve of wheat root to arsenate and cadmium mixture solution. Error bar stands for standard error.

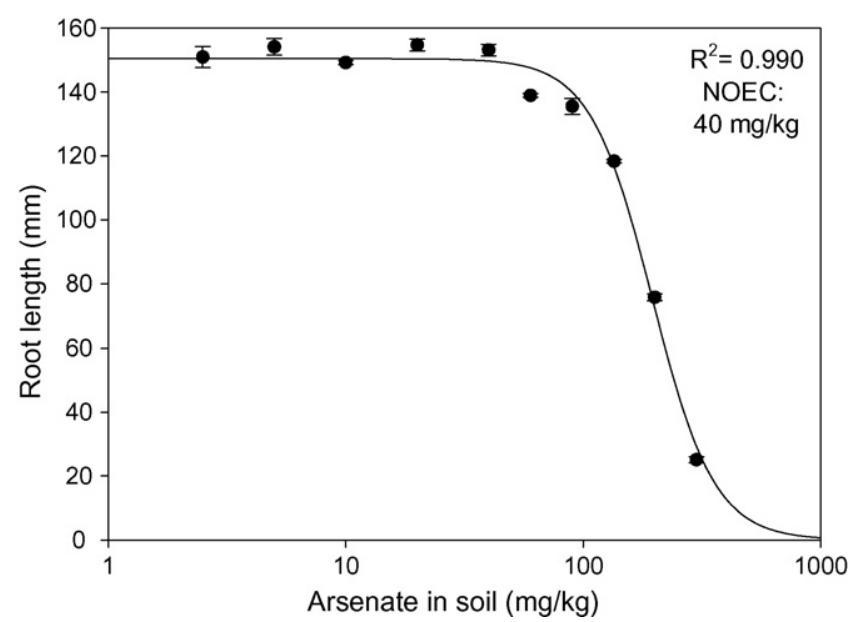

Fig. 4. Observed responses and fitted curve of wheat root to soil arsenate. NOEC was assessed using Dunnett's procedure (at a 5\% significance level) on the data. Error bar stands for standard error.

soils with different properties, with a higher moisture content $(40 \%)$ and without undergoing ageing process; all of these factors may have contributed to the higher toxicity of the later test.

\subsection{Combined toxicity in soil}

An equitoxic combined experiment for $\mathrm{As}$ and $\mathrm{Cd}$ spiked soil was conducted based on the soil single toxicant exposure data. The combined test was composed according to Table 3 . The combined effect curve (Fig. 6) useing $\mathrm{TU}_{\text {mix }}$ as the horizontal axis, and the regression result indicated that the $\mathrm{EC}_{50}$ was $1.49 \mathrm{TU}_{\text {mix }}$, which means, a mixture contamination of $147 \mathrm{mg} \mathrm{kg}^{-1}$ As $\left(0.75 \mathrm{TU}_{\mathrm{As}}\right)$ and $337 \mathrm{mg} \mathrm{kg}^{-1} \mathrm{Cd}\left(0.75 \mathrm{TU}_{\mathrm{Cd}}\right)$ would inhibit root elongation by $50 \%$ compared with the control. The value of AI was -0.33 ( -0.38 to -0.28$)$, therefore, As and $\mathrm{Cd}$ had a less than additive toxicity to wheat root in the soil.

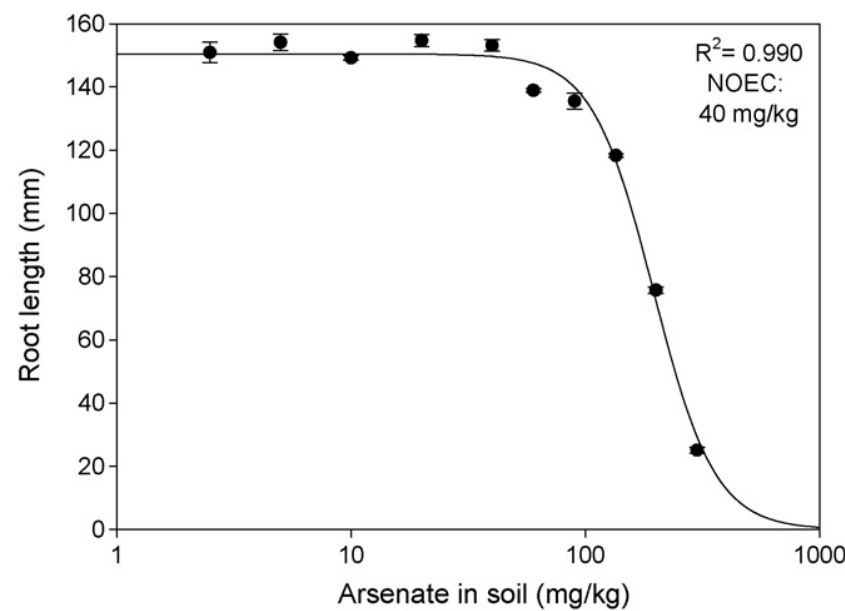

Fig. 5. Observed responses and fitted curve of wheat root to soil cadmium. NOEC was assessed using Dunnett's procedure (at a 5\% significance level) on the data. Error bar stands for standard error. 
Table 3

Composition of combined test in soil experiment

\begin{tabular}{ll}
\hline Treatment $\left(\mathrm{TU}_{\text {mix }}\right)$ & $\begin{array}{l}\text { As conc. }(\mu \mathrm{M})\left(\mathrm{TU}_{\mathrm{As}}\right)+\mathrm{Cd} \text { conc. } \\
(\mu \mathrm{M})(\mathrm{TU} \mathrm{Cd})\end{array}$ \\
\hline $1(0)$ & $0(0)+0(0)$ \\
$2(0.1)$ & $9.8(0.05)+22.4(0.05)$ \\
$3(0.2)$ & $19.6(0.1)+44.9(0.1)$ \\
$4(0.4)$ & $39.2(0.2)+89.8(0.2)$ \\
$5(0.8)$ & $78.4(0.4)+179.6(0.4)$ \\
$6(1.2)$ & $117.6(0.6)+269.4(0.6)$ \\
$7(1.6)$ & $156.8(0.8)+359.2(0.8)$ \\
$8(2)$ & $196(1)+449(1)$ \\
$9(3.2)$ & $313.6(1.6)+718.4(1.6)$ \\
\hline
\end{tabular}

\subsection{Mode of interaction for As and Cd}

It seems that the direction changes for interaction of As and $\mathrm{Cd}$ when the two elements were present simultaneously in solution or in soil. In order to comprehend the notable difference between solution and soil on their $\mathrm{EC}_{50}$ value and combined effects, we used Visual MINTEQ (Version. 2.30, Department of Land and Water Resources Engineering, KTH, Sweden) to calculate solution speciation data [32,33]. Most of the As and $\mathrm{Cd}$ added were in active forms or toxic forms $\left(\mathrm{Cd}^{2+}\right.$ and $\mathrm{H}_{2} \mathrm{AsO}_{4}{ }^{-} / \mathrm{HAsO}_{4}{ }^{2-}$ ) in solutions. Labile soil As and $\mathrm{Cd}$ were extracted using $0.1 \mathrm{M} \mathrm{NaNO}_{3}$ with a soil:solution ratio of 1:50 [34] to investigate the proportion of extractable elements. However, the $\mathrm{EC}_{50}$ and NOEC values expressed with labile As and $\mathrm{Cd}$ showed a reversal of the toxic orders for $\mathrm{Cd}$ and $\mathrm{As}$, with $\mathrm{Cd}$ 5 times more toxic than As (data not shown). This means $\mathrm{Cd} / \mathrm{As}$ contents extracted with $0.1 \mathrm{M} \mathrm{NaNO}_{3}$ could not represent toxic forms, or the extraction data cannot fully explain the difference between soil and solution. Since the extraction conditions under which availability is measured always differ greatly from the field condition, and to large extent "availability" is composed of different speciation with different toxicity, caution should be exercised when using extraction data to explain the toxicity.

Combined anions affect the toxicity of $\mathrm{Cd}$ according to their types and content. In a soil with high level of chloride,

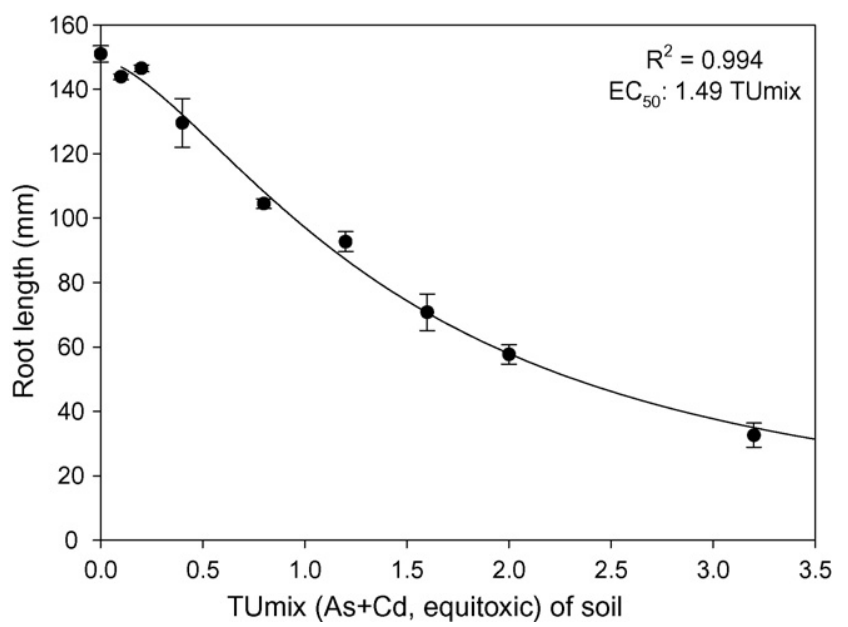

Fig. 6. Responses and fitted curve of wheat root to soil mixed with arsenate and cadmium. Error bar stands for standard error. the phytoavailablity of $\mathrm{Cd}$ is enhanced by forming stable and uptake-facilitating chloride complexes [35]. On the other hand, soil characteristics $(\mathrm{pH}$, organic matter, adsorption capacity and moisture) and factors (ageing) also affect the availability and subsequently its toxicity in the complicated soil matrix $[21,31,36]$. Many compounds of As or Cd (for example, $\left.\mathrm{Cd}_{3}\left(\mathrm{AsO}_{4}\right)_{2}\right)$ have very low solubility product $\left(K_{\mathrm{sp}}\right)$ values so precipitation could be formed to reduce the active concentration.

As and Cd exists in solution as ions of different charge, i.e. negative and positive, they may interact on the root surface and then affect each other uptake processes by plants [37]. We hypothesize that positively charged $\mathrm{Cd}$ is easy to be absorbed to the surface of biomembranes which always have negative charge, so the total charge of membrane more close to neutral, thus the negative anion of arsenate is easier to reach the root surface thus more chance of being taken up by plant roots. This may be part of the reason why As and $\mathrm{Cd}$ in solution had a more than additive toxicity, but needs further investigation.

Hochadel and Waalkes [38] reported a test about the sequence of toxicants applied on rats. If pretreated with a NOEC concentration of As, decreased rat mortality compares well with the group only treated with $\mathrm{Cd}$. However, when the exposure order was reversed, there had no significant effect of Cd to As. Exposure history could have a significant influence on the combined effect. Furthermore, interactions of two toxicants may occur at different levels, within the soil, during the uptake processes and on the target sites in the cell [27]. Both toxicants are associated with the antioxidant system (for example metallothionein and glutathione) in cells. A study by Sneller et al. on Silene Vulgaris showed that As and Cd had additive effects on phytochelatins contents [15], which indicated that the interactions at the physiological level are important topics in need of further research.

When assessing the mixture toxicity, it should not hasten to say the elements act strictly similar or independently, usually their action modes are intervenient of the extremes. We had known that both As and Cd could affect the plant growth by inducing oxidation stress or enzyme content fluctuation and other factors. On the other hand, different shapes of concentration-effect curves in our result show that their interactions were not simple similar action.

In general, metal interactions may potentially occur at lower concentrations, more work needs to be conducted, for example, to use alternative methodology other than the simple similar action mode.

\section{Conclusions}

Generally speaking, arsenate is more toxic than cadmium to wheat root elongation. At the lower concentrations, As may have less toxicity or even exhibit stimulation effect. Our solution culture experiment showed that the simultaneous exposure to As and Cd not only produced a toxicity higher than the single exposure, but also with a magnitude larger than the value predicted with a simple similar active mode or concentration addition. In the complex soil matrix, the active or the more toxic forms of metal may dramatically decline from metal-soil interactions, 
so the combined effects judged from nominal concentration appears to exhibit antagonism. The extractable fraction of metals cannot represent the actual toxic parts of the metal in soils. Therefore, simple additive mode should be used with caution to study the interactions of multiple toxicants in soil.

\section{Acknowledgements}

This study was supported by the Ministry of Science and Technology of China (2007CB407304), the Natural Science Foundation of China (No. 40321101) and Chinese Academy of Sciences (KZCX3-SW-431).

\section{References}

[1] Organisation for Economic Co-operation and Development (OECD), Guideline for Testing of Chemicals 208, Terrestrial Plant Test: Seedling Emergence and Seedling Growth Test, OECD, Paris, 2003.

[2] United States Environmental Protection Agency (USEPA), Ecological Effects Test Guidelines, OPPTS 850.4200: Seed Germination/Root Elongation Toxicity Test, OPPTS, Washington, DC, 1996.

[3] F.M. Cheng, N.C. Zhao, H.M. Xu, Y. Li, W.F. Zhang, Z.W. Zhu, M.X. Chen, Cadmium and lead contamination in japonica rice grains and its variation among the different locations in southeast China, Sci. Total Environ. 359 (2006) 156-166.

[4] United States Environmental Protection Agency (USEPA), Ecological Effects Test Guidelines, OPPTS 850.4230: Early Seedling Growth Toxicity Test, OPPTS, Washington, DC, 1996.

[5] Organisation for Economic Co-operation and Development (OECD), Guideline for Testing of Chemicals 227, Terrestrial Plant Test: Vegetative Vigour Test, OECD, Paris, 2003.

[6] L.W. Chang, J.R. Meier, M.K. Smith, Application of plant and earthworm bioassays to evaluate remediation of a lead-contaminated soil, Arch. Environ. Contam. Toxicol. 32 (1997) 166-171.

[7] United Stated Environmental Protection Agency (USEPA), Guidance for developing ecological soil screening levels, OSWER Directive 9285.7-55. OSWER, Washington, DC, 2003.

[8] A.X.R. Corrêa, L.R. Rörig, M.A. Verdinelli, S. Cotelle, J.F. Férard, C.M. Radetski, Cadmium phytotoxicity: Quantitative sensitivity relationships between classical endpoints and antioxidative enzyme biomarkers, Sci. Total Environ. 357 (2006) 120-127.

[9] Y.J. An, Soil ecotoxicity assessment using cadmium sensitive plants, Environ. Pollut. 127 (1) (2004) 21-26.

[10] International Programme on Chemical Safety (IPCS), Environmental Health Criteria 134: Cadmium, World Health Organization, Geneva, 1992.

[11] International Programme on Chemical Safety (IPCS), Environmental Health Criteria 224: Arsenic and arsenic compounds, World Health Organization, Geneva, 2001.

[12] Agency for Toxic Substances and Disease Registry (ATSDR), CERCLA Priority List of Hazardous Substances, GA, US Department of Health and Human Services (www.atsdr.cdc.gov), 2005.

[13] M. Patra, N. Bhowmik, B. Bandopadhyay, A. Sharma, Comparison of mercury, lead and arsenic with respect to genotoxic effects on plant systems and the development of genetic tolerance, Environ. Exp. Bot. 52 (3) (2004) 199-223.

[14] M.E. Wang, Q.X. Zhou, Single and joint toxicity of chlorimuron-ethyl, cadmium, and copper acting on wheat Triticum aestivum, Ecotoxicol. Environ. Saf. 60 (2) (2005) 169-175.

[15] F.E.C. Sneller, L.M. Van Heerwaarden, H. Schat, J.A.C. Verkleij, Toxicity, metal uptake, and accumulation of phytochelatins in Silene Vulgaris exposed to mixtures of cadmium and arsenate, Environ. Toxicol. Chem. 19 (12) (2000) 2982-2986.

[16] J. Liu, Y.P. Liu, S.M. Habeebu, M.P. Waalkes, C.D. Klaassen, Chronic combined exposure to cadmium and arsenic exacerbates nephrotoxicity, particularly in metallothionein-I/II null mice, Toxicology 147 (3) (2000) 157-166.

[17] T. Dasgupta, S.A. Hossain, A.A. Meharg, A.H. Price, An arsenate tolerance gene on chromosome 6 of rice, New Phytol. 163 (2004) 45-49.

[18] A.L. Charles, S.J. Markich, P. Ralph, Toxicity of uranium and copper individually, and in combination, to a tropical freshwater macrophyte (Lemna aequinoctialis), Chemosphere 62 (8) (2006) 1224-1233.

[19] Y.P. Kalra, Determination of $\mathrm{pH}$ of soils by different methods: collaborative study, J. AOAC Int. 78 (1995) 310-320.

[20] D.W. Nelson, L.E. Sommers, Total carbon, organic carbon, and organic matter, in: J.M. Bartels (Ed.), Methods of Soil Analysis (Part 3, Chemical Methods), Soil Sci. Soc. Am. and Am. Soc. Agron., Madison, WI, USA 1996, pp. 961-1010.

[21] X.Y. Tang, Y.G. Zhu, Y.S. Cui, J. Duan, L.L. Tang, The effect of ageing on the bioaccessibility and fractionation of cadmium in some typical soils of China, Environ. Int. 32 (5) (2006) 682-689.

[22] C.W. Dunnett, A multiple comparison procedure for comparing several treatments with a control, J. Am. Stat. Assoc. 50 (1955) 1096-1121.

[23] J. Jensen, L.E. Sverdrup, Joint toxicity of linear alkylbenzene sulfonates and pyrene on Folsomia fimetaria, Ecotoxicol. Environ. Saf. 52 (1) (2002) $75-81$.

[24] J.B. Sprague, B.A. Ramsay, Lethal levels of mixed copper-zinc solutions for juvenile salmon, J. Fish. Res. Board Can. 22 (1965) 425-432.

[25] Y.J. An, Y.M. Kim, T.I. Kwon, S.W. Jeong, Combined effect of copper, cadmium, and lead upon Cucumis sativus growth and bioaccumulation, Sci. Total Environ. 326 (2004) 85-93.

[26] M.H.S. Kraak, S.C. Stuijfzand, W. Admiraal, Short-term ecotoxicity of a mixture of five metals to the zebra mussel Dreissena polymorpha, Bull. Environ. Contam. Toxicol. 63 (1999) 805-812.

[27] L. Posthuma, R. Baerselman, R.P.M. Van Veen, E.M. Dirven-Van Breemen, Single and joint toxic effects of copper and zinc on reproduction of Enchytraeus crypticus in relation to sorption of metals in soils, Ecotoxicol Environ. Saf. 38 (2) (1997) 108-121.

[28] L.L. Marking, V.K. Dawson, Method for assessment of toxicity or efficacy of mixtures of chemicals, U.S. Fish and Wildlife Service, Invest. Fish Contr. 67 (1975).

[29] X.L. Liu, S.Z. Zhang, X.Q. Shan, Y.G. Zhu, Toxicity of arsenate and arsenite on germination, seedling growth and amylolytic activity of wheat, Chemosphere 61 (2) (2005) 293-301.

[30] J. Clark, L.S. Ortego, A. Fairbrother, Sources of variability in plant toxicity testing, Chemosphere 57 (11) (2004) 1599-1612.

[31] J. Song, F.J. Zhao, F.P. McGrath, Y.M. Luo, Influence of soil properties and aging on arsenic phytotoxicity, Environ. Toxicol. Chem. 25 (6) (2006) $1663-1670$

[32] H. Kola, K.J. Wilkinson, Cadmium uptake by a green alga can be predicted by equilibrium modelling, Environ. Sci. Technol. 39 (9) (2005) 30403047.

[33] Q. Sun, X.R. Wang, S.M. Ding, X.F. Yuan, Effects of exogenous organic chelators on phytochelatins production and its relationship with cadmium toxicity in wheat (Triticum aestivum L.) under cadmium stress, Chemosphere 60 (2005) 22-31.

[34] Y. Cai, J.C. Cabrera, M. Georgiadis, K. Jayachandran, Assessment of arsenic mobility in the soils of some golf courses in South Florida, Sci. Total Environ. 291 (2002) 123-134.

[35] R.G. Garrett, A.I. MacLaurin, E.J. Gawalko, R. Tkachuka, G.E.M. Hall, A prediction model for estimating the cadmium content of durum wheat from soil chemistry, J. Geochem. Exp. 64 (1998) 101-110.

[36] W. Jiang, S.Z. Zhang, X.Q. Shan, M.H. Feng, Y.G. Zhu, R.G. McLaren, Adsorption of arsenate on soils. Part 2: Modeling the relationship between adsorption capacity and soil physiochemical properties using 16 Chinese soils, Environ. Pollut. 138 (2) (2005) 285-289.

[37] E. Smith, R. Naidu, A.M. Alston, Chemistry of inorganic arsenic in soil: II. Effect of phosphorus, sodium, and calcium on arsenic sorption, J. Environ. Qual. 31 (2002) 557-563.

[38] J.F. Hochadel, M.P. Waalkes, Sequence of exposure to cadmium and arsenic determines the extent of toxic effects in male Fischer rats, Toxicology 116 (1997) 89-98. 